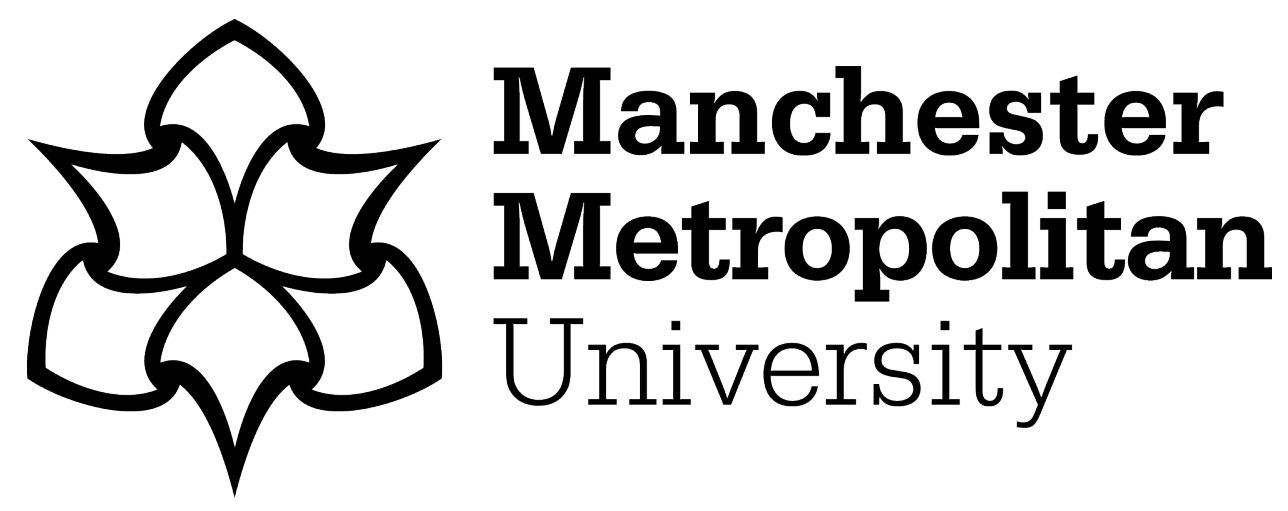

Lewis, KV, Cassells, S and Roxas, H (2014) SMEs and the Potential for A Collaborative Path to Environmental Responsibility. Business Strategy and the Environment, 24 (8). pp. 750-764. ISSN 1099-0836

Downloaded from: https://e-space.mmu.ac.uk/621508/

Publisher: Wiley

DOI: https://doi.org/10.1002/bse.1843

Please cite the published version 


\title{
SMEs and the Potential for A Collaborative Path to Environmental Responsibility
}

\author{
Kate V. Lewis, ${ }^{1 *}$ Sue Cassells ${ }^{2}$ and Hernan Roxas ${ }^{3}$ \\ ${ }^{1}$ School of Management, Massey University, Wellington, New Zealand \\ ${ }^{2}$ School of Economics and Finance, Massey University, Palmerston North, New Zealand \\ ${ }^{3}$ School of Management and Marketing, Deakin University, Melbourne, Australia
}

\begin{abstract}
Globally, the potential for small and medium-sized enterprises (SMEs) to collectively impact negatively on the environment is great. Therefore, the adoption, and maintenance, of environmentally responsible practices by this group of firms is especially critical. Studies of environmental practices successfully implemented by small firms have revealed that relationships with other firms, or other organizations, can contribute to greater awareness of the benefits of such activities and, therefore, enhance the possibility of environmental engagement. Collaborative relationships may provide opportunities for SMEs to overcome some of the barriers to implementing environmental initiatives associated with their size, and/or associated characteristics. This paper focuses on attitudes of SME owner-managers to a variety of environmental issues (including regulation and voluntary standards), and to collaborating with other firms (in either a formal or informal sense). The data this paper draws upon are from two waves of an ongoing longitudinal survey of New Zealand SMEs. Copyright @ 2014 John Wiley \& Sons, Ltd and ERP Environment
\end{abstract}

Received 06 August 2013; revised 23 December 2013; accepted 28 December 2013

Keywords: small and medium enterprises; New Zealand; environmental management; sustainability; collaboration

\section{Introduction}

N MANY COUNTRIES AROUND THE GLOBE, THE POTENTIAL FOR SMALL AND MEDIUM-SIZED ENTERPRISES (SMES) COLLECTIVELY to impact negatively on the environment is great (Wilson et al., 2012). This is especially true in New Zealand, where $97 \%$ of the total business population are firms employing 19 or fewer people (MED, 2011). The adoption, and

maintenance, of environmentally responsible practices by this group of

firms is, therefore, critical. However, whilst in theory this sounds a logical and reasonable assertion, it is, in reality and for many reasons, a complex proposition (Masurel, 2007). Reasons for this vary and can include sectoral issues (for example, difficulty in encouraging SME owner-mangers to adopt new initiatives and engage in formal training), industry issues (e.g. norms and standards affecting SMEs in specific industries) and issues at the firm level (e.g. the structure and management of the individual enterprises) (Gonzalez-Benito and Gonzalez-Benito, 2005). Overall, a corollary of the consequences of the challenges faced by SMEs in addressing issues of environmental responsibility is that environmental management related improvements are perceived as being more a 'lose-lose' than the promised 'win-win' (Vernon et al., 2003).

${ }^{*}$ Correspondence to: Kate V. Lewis School of Management, Massey University, Wellington, New Zealand.

E-mail: K.V.Lewis@massey.ac.nz 

There is an increasing body of research examining environmental practices in the small firm context that tend to cluster around a number of key themes. These include barriers to uptake (see, e.g., Cote et al., 2006; Taylor et al., 2003), perceived costs and benefits of implementation (see, e.g., European Commission, 2002; Ilomaki and Melanen, 2001), the role of regulation (see, e.g., Petts, 2000), motivational antecedent factors (see, e.g., Hutchinson and Hutchinson, 1995), the links between enhanced environmental performance and the firm's bottom line (see, e.g., Gonzalez-Benito and Gonzalez-Benito, 2005) and the suitability of formal environmental management standards (see, e.g., Biondi et al., 2000). Many studies have explored these topics in terms of a specific industry (e.g. manufacturing by Williamson et al., 2006) and/or geographic context (e.g. the UK by Revell and Rutherfoord, 2003). Whilst necessary, such a thematic approach has resulted in a somewhat fragmented understanding, and in an approach that favours recording what has occurred, rather than hypothesizing what strategies might be deployed in the future to reverse the trend in poor SME engagement with environmental management (Parker et al., 2009).

Attitudinally, many SME owner-managers reportedly consider their firm to have no impact on the environment (see, e.g., Rowe and Hollingsworth, 1996; Simpson et al., 2004; Vernon et al., 2003). This attitudinal cohort typically also expects government to take responsibility for environmental management and, in doing so, ensure that there is a 'level playing field' for all businesses (Rutherfoord et al., 2000). Whilst in some quarters this might be viewed as comforting (in that it implies that firms will be compelled), it is in many ways worrying given that studies have demonstrated that in many countries SME owner-managers may, at best, be ignorant of their obligations when it comes to legislation (Patton and Worthington, 2003), or, at worst, deliberately flout the rules where possible. The potential result, therefore, is both an abdication of individual firm responsibility and reticence in engaging from a compliance standpoint. One of the potential outcomes of a reliance on government to dictate levels of environmen- tal performance for firms is the perpetuation of the myth that 'compliance is enough' (Wilson et al., 2011). It fails to encourage, or stimulate, leadership, best practice or innovation in this domain. In turn, the lack of voluntary action contributes to the number of SME 'laggards' in terms of environmental responsibility, and does little, if anything, to dispel the notion that there is nothing, to be gained from being a 'green leader' (assessment would suggest the sector is characterized by more laggards than leaders). Whilst accusations of oversimplification could be levelled at this type of categorization of SME responses to the green imperative, and accepting that there does exist nuance in terms of attitudes and behaviours (Battisti and Perry, 2011; Collins et al., 2010), it does serve to illustrate that within the SME sector there are participative polarities in regard to attitude, action and intention.

In terms of moving towards being an environmentally responsible firm, studies on practices successfully implemented by small firms have revealed that relationships with other firms, or other organizations outside the firm, can contribute to greater awareness of the benefits of such activities - as well as enhancing the potential for actual environmental engagement. It appears that inter-firm collaboration as an enabler of environmentally responsible behaviour in small firms is gaining both credence and interest in the domains of both theory and practice. To date attention has typically focused on supply chain relationships (see, e.g., Ciliberti et al., 2008) and studies have found, for example, that they are important for the dissemination of environmental information (Williamson and Lynch-Wood, 2001), and that suppliers are in a position to assist with environmental innovations because of the existing and non-threatening relationships with firms (Mir and Feitelson, 2007). However, recent work has seen this relationship oriented focus expanded to include SMEs as environmental collaborators - both with others SMEs and with other organizations (e.g. industry organizations, or those tasked with furthering environmental responsibility).

Collaborative relationships may, therefore, provide the opportunity for SMEs to overcome some of the barriers to implementing environmental initiatives associated with their size, and/or other characteristics - for example, to assist in dealing with those barriers associated with firm structure (del Brio and Junquera, 2003) and limited absorptive capacity (Lepoutre and Heene, 2006). In the New Zealand context, Collins et al. (2007) found that network membership was positively associated with adopting sustainably oriented practices, and such membership was more important, and therefore influential in terms of action, for smaller firms than for large firms. The potential benefits of a partnership approach to environmental responsibility may be especially enabling for the $69 \%$ of New Zealand firms (323 935) that employ no staff at all (MED, 2011). As diminished absorptive capacity, less resource slack, and an under-developed strategic focus are consistently reported characteristics of micro-enterprises, they are likely to find the barriers even more burdensome (Mir, 2008; Mir and Feitelson, 2007). 
It would, therefore, seem both prudent and timely to consider what potential there is for collaborative approaches to contribute to enhancing the effective and proactive engagement of SMEs with responsible environmental practices. Or as Verheul suggested: shift focus 'from "factors" influencing individual firms, to the relations and interactions between "actors"' (1999, p. 218). There exists little empirical evidence or discussion of the actual, or potential, application of such collaborative solutions, but increasingly articulations are being made as to both need and value (Agan et al., 2013; Burch et al., 2013; European Commission, 2002; Hofmann et al., 2012; Yarahmadi and Higgins, 2012). Therefore, in recognition of this gap and the relative infancy of environmental management in the context of SMEs (Brammer et al., 2012), and as a modest contribution to the knowledge base, the objective of this paper is to focus on attitudes of SME owner-managers to a variety of environmental issues (including regulation and voluntary standards) and to collaborating with other firms (in either a formal or an informal sense). The data this paper draws upon are from two waves of an ongoing longitudinal survey of New Zealand SMEs. Whilst not explicitly designed to link attitudes to environmental engagement with collaboration, the findings of the survey were used as a stimulus for considerations of collaboration as a potential pathway to enhancing levels of engagement with environmentally responsible actions by SMEs.

\section{Existing Research}

As SMEs continue to be a group among global business populations that lag with regard to environmental responsibility, substantial attention has been given to mechanisms by which to engage them with the issue of sustainability, and in particular to strategies by which they may mitigate the negative environmental impact of their own firms on the environment. Research has shown that while the agenda within the firm is critical - and particularly the vision and values of the individual owner-manager (Aragon-Correa et al., 2008; Collins et al., 2007; Dewhurst and Thomas, 2003; Kearins and Collins, 2012; Studer et al., 2006) - there tends to be a chronic attitude-action gap that pervades the SME context (Drake et al., 2004; Gadenne et al., 2009; Redmond et al., 2008; Revell et al., 2009; Tilley, 1999; Tilley et al., 2003; Williams and Schaefer, 2013). That is, while SME owner-managers may frequently possess a positive attitude towards the environment (manifested in behaviours in their home domain for example), it consistently fails to translate into action in the context of their firm. The multitude of reasons behind this tend to stem from where the locus for environmental responsibility is perceived as existing, and how, or perhaps if, personal and business objectives are reconciled (Welford, 1994). Suffice to say, while the peculiarity of the value-behaviour gap remains unexplained but drawing attention (Cassells and Lewis, 2011; Tilley, 1999), emphasis has shifted to environmental stimulators that exist beyond the boundaries of the firm (Bianchi and Noci, 1998): external stakeholders (e.g. trade or industry associations, suppliers, customers etc.), and how collaboration with such stakeholders may advance environmental actions in SMEs.

Pressure from a range of external stakeholders is often reported as being a significant driver in enacting behavioural change in firms with regard to environmental responsibility. Such pressure is reported as being effective at stimulating firms to behave proactively in environmental terms, or run the risk of weakening their brand and/or reputation in the marketplace (Studer et al., 2006). Research has shown that this pressure is not directed at small firms in the same way as large firms, and consequently does not result in the same changes. Indeed, work has shown that external pressure is infrequently reported by SME owner-managers as being of any influence at all on their environmental practices (Collins et al., 2007; Lawrence et al., 2006; Tilley et al., 2003). Some authors have concluded that this absence of pressure on small firms can be traced to their lack of 'visibility' (in comparison to large firms). However, work has shown that SMEs are equally visible, albeit in different ways. That is, they are visible at a community, rather than country, level (Lepoutre and Heene, 2006). Whatever the reasoning, the reported reality is that SMEs are not experiencing customer or supply chain pressure that is stimulating them to change behaviour or engage in new practices (European Commission, 2002; Howarth and Fredericks, 2012).

Presenting environmental responsibility as an opportunity for SMEs to exploit customer demand for green products and build market niches around green consumers therefore appears to have proven to be not a particularly sound rationale, or at least not one that has resonated to date. Research suggests that SMEs either are not experiencing 'green demand', or remain insufficiently convinced that the investment in such a strategy will reap the promised 
rewards (Revell and Blackburn, 2007). Similarly, green supply chain management (GSCM) - often put forward as the 'silver bullet' for SME environmental management engagement - also lacks an evidential base to suggest it is a viable solution for awakening the green imperative in the SME context. The expectation is that GSCM requirements demanded of SMEs by their larger partners at the head of the supply chain will stimulate changes in practices (Patton and Baron, 1995), which may in turn be passed on to suppliers of those SMEs (Ayuso et al., 2013). Broader ambitions would see SMEs placing expectations on their own suppliers to also prove green credentials - by acting as 'green buyers' (Moore and Manring, 2009) - or, if proactive with regard to environmental strategies, using this leadership to leverage change further up the supply chain. Whilst SMEs being expected to meet environmental standards set by large suppliers is a relatively common phenomenon, research suggests that SMEs lack the power to truly exert pressure up supply chains they are part of, or down any supply chains they may head (Lepoutre and Heene, 2006; Revell et al., 2009; Rutherfoord et al., 2000; Williamson and Lynch-Wood, 2001; Worthington and Patton, 2005). Whilst collaborative approaches to the pursuit of a green agenda may be more idealistic than the norm for SMEs currently, this paper will postulate that incremental steps, and specifically those outside business to business relationships, are worthy of consideration.

Supplier relationships could be categorized as one of the more well understood external alliances in which SMEs engage. The difficulties SMEs face in identifying and enacting external relationships (in a variety of contexts) is well established and is said to stem from a number of dimensions, including power imbalances, issues of trust, and the management structures and capabilities that exist within the firm (del Brio and Junquera, 2003; Lepoutre and Heene, 2006). A deficit of knowledge and capability on the part of SME owner-managers to initiate and/or strengthen external partnerships may also be a significant factor. Additionally, the very characteristics that frequently drive their business endeavours, such as the strong need for personal autonomy and the preservation of the firm as an independent unit (Russo and Perrini, 2009), may at best be inconsistent with collaborative approaches, or at worst sabotage any efforts that might be made to encourage them to do so. However, the benefits of strategic external alliances for SMEs are well established - for example for assisting with internationalization (Coviello and Munro, 1997), growth and diversification (Wynarczyk and Watson, 2005) and information accumulation and dispersion (Chaston and Mangles, 2000). However, little consensus exists around the best ways for SMEs to overcome the substantial barriers they are said to face in establishing such collaborative external relationships.

Despite the proven difficulties, a growing number of studies are demonstrating how, in a variety of contexts, partnership approaches to sustainability (beyond those embodied in GSCM principles) are empowering SMEs with regard to environmental responsibility - for example cleaner production in Dutch SMEs through partnerships with local authorities (Gombault and Versteege, 1999), the role of intermediate organizations supporting environmental improvements in SMEs in the Netherlands (Hoevenagel and Wolters, 2000), private-public networks focusing on sustainability for tourism SMEs in four European countries (Halme and Fadeeva, 2000) and business supply chain partnerships in Hong Kong and China (Cheung et al., 2009). In terms of specific collaborative initiatives, examples include Enviroclub, instigated by a number of federal government agencies in Canada, whereby 10-15 SMEs form a club in order to execute a pollution prevention project (Huppe et al., 2006); oriented to a similar clustering format are the waste minimization clubs that were implemented under the UK's waste strategy in order to facilitate both waste reduction and financial savings for participant firms (Pratt and Phillips, 2000) and Ecoprofit, a German intermediary industry based programme that (in partnership with local authorities and consultants) worked with SMEs to introduce concepts of sustainable development via eco-innovation uptake (Hansen and Klewitz, 2013; Klewitz et al., 2012).

Collaborative approaches reportedly capitalize on formal and informal networking activities that SMEs already participate in (Tilley, 1999), and are most successful when relationships are formed on a voluntary basis (del Brio and Junquera, 2003) (which is consistent with management imperatives and styles typically found within SMEs). Linkages with external organizations are said to enhance opportunities for environmental engagement in a number of ways, but principally by those organizations providing environmentally oriented information and expertise, or as hubs through which co-operative alliances between SMEs can be established (European Commission, 2002; Setzer and Biderman, 2013). Trade, industry and employer organizations are said to be particularly effective in this regard (Bianchi and Noci, 1998; Holland and Gibbon, 1997; Patton and Worthington, 2003), especially because they possess a non-regulatory and non-competitive role in relation to the SMEs with which they interact - thereby implicitly enhancing levels of trust (Mir and Feitelson, 2007). Some have however queried the ability of trade associations to fulfil 
this role, suggesting that due to the passive nature of membership they will be unlikely to achieve more than being an information channel (Rutherfoord et al., 2000). In general, research implies that collaborative approaches to environmental issues in the SME context have the potential 'to make solving challenging environmental problems easier or more effective' (Sharfman et al., 2009, p. 11).

\section{Methodology}

The sample for this study was drawn from two waves of an ongoing longitudinal survey of New Zealand SMEs ${ }^{1}$ (who were originally sourced via a commercial provider of business databases). One phase of the survey included questions (with varying response formats) used to ascertain the attitudes of SME owner-managers toward environmental issues in New Zealand. An additional phase included questions designed to measure the extent to which SME owner-managers engage in collaboration with other firms as well as the perceived benefits of and barriers to collaboration. Dillman's (2000) Total Design Method was used to guide sample selection, and development, design and pilot testing of the questionnaire. The survey was carried out over four mail-outs: the first mail-out included a cover letter, the questionnaire and a prepaid envelope, and the second, third and last mail-outs consisted of a reminder/ postcard, a letter and another reminder/postcard respectively. The unit of analysis of this study was at the level of the individual - hence all mail-outs were addressed to the owners and/or managers of the firms, being the intended respondents of the survey.

The first mail survey (from which the data on collaboration are drawn) was sent to a random sample of 5500 firms across New Zealand. After excluding 825 ineligible and unreachable firms there were 1361 usable responses, giving a response rate of $29 \%$. A subsequent survey (from which the data on attitudes towards environmental issues are drawn) involved 4340 firms (including the 1361 firms who responded to the 2007 survey). After excluding 447 ineligible and unreachable firms there were 1554 usable responses, giving a response rate of $40 \%$. The response rate for both waves of the survey exceeds the average response rate of $27 \%$ involving studies of small firms (Bartholomew and Smith, 2006). In addition, 740 of the 1361 SME owner-managers who responded to the collaboration sections also took part in the subsequent wave and therefore answered the environmentally oriented questions also.

In order to check for non-response bias, a comparison of the demographic profile (age, gender, firm size and industry) was made between respondents who replied to both surveys and those who replied to the first but not the second (Armstrong and Overton, 1977). The insignificant differences between the two groups of respondents suggested that non-response bias was non-existent or too small for detection. To account for common method bias given that a single instrument was used to measure all the variables of the study, Harman's single-factor test was performed on selected items (Podsakoff et al., 2003). Four factors emerged from the unrotated factor solution, with the first factor accounting for only $30 \%$ of the variance in the variables. Whilst this approach of common method bias detection has its own limitations, the results offer some evidence that common method bias per se could not explain the variations in the responses to the questions.

Respondents were also asked to provide owner-manager-specific data, i.e. age and gender, and firm-specific data, including number of full-time employees as a proxy for firm size, industry (i.e. manufacturing or service) and whether the business was family owned or otherwise. In addition to the findings for all firms, tests were conducted in order to measure significant differences regarding attitudes toward environmental issues, participation in firm collaboration, and benefits of and barriers to collaboration, according to firm size and type and the age and gender of the SME owner-manager. To achieve this, $X^{2}$, Student's $t$ test, and ANOVA were used depending on the type of data (i.e. categorical, discrete or continuous). Thus, for example, the $X^{2}$ test can be used when we ask whether knowledge of the ISO 14001 EMS standard is independent of firm size. The Pearson $X^{2}$ statistic answers this by comparing observed values according to firm size with expected values based on the total sample responses. Along with the $X^{2}$ statistic, where there is an observed difference, the magnitude of Cramer's V statistic provides insight into the size

\footnotetext{
${ }^{1}$ A classification of SMEs according to full-time equivalent employees (FTEs) has been utilized, identifying micro-enterprises as those with at most five FTEs, small enterprises as those with six to 49 FTEs and medium enterprises as those with 50 to 99 FTEs (Cameron and Massey, 1999).
} 
effect of this difference (the larger the statistic, the greater the size effect). The same is the case for the $r$ statistic with Student's $t$ tests and $\dot{\omega}^{2}$ with the ANOVA test.

The final analysis involved grouping the 740 owner-managers who responded to both waves of the survey based on whether their firm was (or was not) in formal and/or informal collaboration with other firms. This typology was used to compare attitudes towards the environmental issues of 'collaborators' and 'non-collaborators' and to test for significant differences between the two groups using either $X^{2}$ or Student's $t$ tests.

\section{Results and Discussion}

The results and discussion are presented in three sections: firm demographics; perceptions of SME owner-managers with regard to environmental responsibility; and firm collaboration.

\section{Firm Demographics}

There were 1361 respondents to the collaboration related wave of the survey, of which 807 (59\%) were micro, 492 (36\%) were small and $15(1 \%)$ were medium-sized enterprises (3\% did not respond). Eight hundred and eighty-four firms $(65 \%)$ were in the service industry and 477 firms (35\%) were manufacturing, with 649 (49\%) identifying as family businesses. Nine hundred and ninety-nine (73\%) SME owner-managers were male and 335 (25\%) were female $(2 \%$ did not respond). To the environmentally oriented wave of the survey, there were 1554 respondents, 740 of whom were also respondents to the collaboration questions. Of the 1554 firms in the survey, $1032(66 \%)$ were micro, $458(30 \%)$ were small and $26(2 \%)$ were medium-sized enterprises (2\% did not respond). One thousand and fifty firms (68\%) were in the service industry and 504 firms (32\%) were manufacturing, with 816 (54\%) describing themselves as family businesses. Of the owner-managers, $1123(72 \%)$ were male and $398(26 \%)$ were female $(2 \%$ did not respond). Only half of the respondents declared their age, with $6 \%$ of these less than 40 years old, $61 \% 40-59$ years in age, and 33\% 60 years and older (the average age was 55).

\section{Perceptions Regarding Environmental Responsibility}

SME owner-managers were asked who they considered should have primary responsibility for maintaining the physical environment (for example, keeping water and air clean and minimizing disposal of hazardous substances). The results presented in Table 1 show that $13 \%$ of owner-managers thought it the responsibility of the government, while over half thought that both government and business should jointly be responsible for the state of our environment. This is consistent with international research that has shown that SMEs welcome a legislative lead by central or local government on environmental matters (Rutherfoord et al., 2000), but do concede that regulation alone is insufficient to protect the environment (Petts, 2000). There were no significant differences with respect to firm size and type, or age and gender of the owner-manager, in terms of perception, or in terms of the locale of the locus of responsibility for environmental responsibility.

\begin{tabular}{lcc}
\hline Primary responsibility for maintaining physical environment & Respondents & $\%$ \\
\hline Government & 201 & 12.9 \\
Business & 25 & 1.6 \\
Both government and business & 815 & 52.4 \\
Individuals & 284 & 18.3 \\
Don't know & 11 & 0.7 \\
No response & 218 & 14.0 \\
\hline
\end{tabular}

Table 1. SME owner-managers' views on responsibility for maintaining the physical environment 
In Table 2, the responses given by SME owner-managers when asked how they would prefer New Zealand to respond to the issue of climate change are presented. While $27 \%$ wanted to see New Zealand become a global leader, the majority preferred to move at the same pace as other countries. Again, there was no difference when it came to firm size. However, SMEs in the service sector were more likely to prefer that New Zealand become a global leader in its response to climate change (perhaps signalling the possibility of using 'green credentials' as a marketing tool), whilst manufacturers were more likely to prefer that New Zealand move at the same pace as other countries $\left(X^{2}(5)=15.853, p<0.01\right.$, Cramer's $\left.V=0.102\right)$. Younger owners/managers were more likely to prefer New Zealand to become a global leader whilst the older owner-managers would prefer New Zealand to move at the same pace as other countries $\left(X^{2}(5)=14.114, p<0.05\right.$, Cramer's $\left.V=0.135\right)$. This is unsurprising, given that younger generations of New Zealanders have been exposed to, and therefore become familiar with, far higher levels of environmental consciousness, and are often reported to be more idealistic about the future than their older counterparts (Malone, 2001). In addition, male owner-managers were more likely to prefer New Zealand to do the minimum whilst female owner-managers were more likely to prefer New Zealand to become a global leader in responding to climate change $\left(X^{2}(5)=28.163, p<0.01\right.$, Cramer's $\left.V=0.138\right)$.

The Climate Change Response (Emissions Trading) Amendment Act became law in New Zealand on 26 September 2008, allowing for the implementation of an emissions trading scheme (ETS) that would ultimately involve all sectors and all greenhouse gases, being phased in between 2008 and 2013. The scheme enables the provision of the allocation of free 'emission units', following which these units can be traded. Firms wishing to increase their emissions are then required to buy units from those with units to sell as a consequence of reducing their emissions. In the relevant survey, SME owner-managers were asked for their opinion regarding the ETS as a policy approach. Table 3 shows that half disagreed with an ETS (with the majority 'strongly disagreeing'), and only $23 \%$ agreed with the policy approach. Interestingly, only 18 of the 1554 owner-managers did not respond to this question (indicating that it provoked strong opinions, either positive or negative). There were no significant differences in the responses with respect to firm size and owner-manager age or gender. However, manufacturing SMEs were more likely (than service SMEs) to disagree with the ETS as a policy approach $(\mathrm{t}(1534)=2.340, \mathrm{p}<0.05, \mathrm{r}=0.06)$.

\begin{tabular}{lcc}
\hline Preferred New Zealand response to climate change & Respondents & $\%$ \\
\hline Become a global leader & 414 & 26.6 \\
Move at the same pace as other countries & 824 & 53.0 \\
Do a little but not worry too much about it & 169 & 10.9 \\
Do as little as possible & 43 & 2.8 \\
Don't know & 68 & 4.4 \\
No response & 36 & 2.3 \\
\hline
\end{tabular}

Table 2. SME owner-managers' preference for New Zealand's response to climate change

\begin{tabular}{|c|c|c|c|c|c|c|c|c|}
\hline & $\begin{array}{c}\text { Strongly } \\
\text { agree }\end{array}$ & Agree & $\begin{array}{r}\text { Neither agree } \\
\text { nor disagree }\end{array}$ & Disagree & Strongly disagree & $\begin{array}{l}\text { Did not } \\
\text { know }\end{array}$ & Mean & St. dev. \\
\hline $\begin{array}{c}\text { The New Zealand ETS as } \\
\text { a policy approach }\end{array}$ & $3.7 \%$ & $19.1 \%$ & $19.0 \%$ & $22.1 \%$ & $27.8 \%$ & $7.1 \%$ & 3.73 & 1.344 \\
\hline $\begin{array}{l}\text { An ETS will put a price } \\
\text { on carbon. Large } \\
\text { emitters should pay } \\
\text { this price on carbon }\end{array}$ & $4.9 \%$ & $26.7 \%$ & $22.1 \%$ & $22.8 \%$ & $14.5 \%$ & $6.8 \%$ & 3.36 & 1.338 \\
\hline
\end{tabular}

Table 3. SME owner-managers' responses to statements regarding the New Zealand ETS policy

$\mathrm{a}_{1.2 \%} \mathrm{did}$ not respond.

${ }^{\mathrm{b}} 6.9 \%$ did not respond. 
The disapproval of the ETS by respondents is in stark contrast to recent findings from a UK study, in which 53\% of a sample of 220 SMEs agreed that carbon pricing schemes and trading were an essential tool in bringing about a reduction in emissions (Revell et al., 2009). This may be explained by the different types of structure and implementation in terms of schemes undertaken in the UK and New Zealand, as well as indicating the difference between the perception of potential influence and the reality of actual impact. The UK was an early adopter of an ETS prior to the launch of the European Union ETS in 2005. Initially, uptake was voluntary; however, by 2006, the UK had reduced its GHG emissions by 15\% on its 1990 levels (Bertram and Terry, 2010). In addition, the publishing of the Stern Review (2007), and the accompanying publicity, may have heightened the awareness of firms in the UK with regard to climate change and collective responsibility to respond to the issue. In contrast, New Zealand, despite ratifying the Kyoto Protocol in December 2002 and agreeing to return to its 1990 emissions levels by 2012, had done nothing toward that end, and indeed by 2006 emissions were up 25.7\% on 1990 levels (Bertram and Terry, 2010). When the New Zealand ETS was put in place, it was unclear, complex, lacking in transparency and inequitable. New Zealand did not set any industry-wide (or even country-wide) cap on emissions, and whole sectors were exempt from the scheme (e.g. the agricultural sector). Large emitters were given emission units free of charge, and in the absence of a cap could purchase units from outside New Zealand if they wanted to increase their emissions. In addition, major industrial emitters facing increased costs of electricity (as a result of ETS price rises) qualified for a rebate of $90 \%$ of that additional cost (Bertram and Terry, 2010).

Whether respondents disapproved of an ETS in principle or the specifics of the New Zealand scheme in particular is less clear, especially given that only 364 (23\%) of SME owner-managers said they were confident they understood how the ETS would work, with the majority saying they were not confident in their understanding of the scheme (i.e. how informed were the opinions that were expressed). This finding is consistent with a pervasive contradiction that appears to exist within the SME sector in regard to environment regulation: namely that, whilst viewing it as the most acceptable mechanism by which to achieve environmental improvements, owner-managers remain largely ignorant of their obligations under such legislation, or the impact of these implications on their firm's performance (Simpson et al., 2004; Vernon et al., 2003). This limited awareness of relevant environmental legislation is consistently reported as a continuing barrier to environmental change in SMEs (Tzschentke et al., 2008), but also as a corollary of firm size, limited absorptive capacity and the limited resources for sourcing and integrating new knowledge (Halme and Korpela, 2013).

SME owner-managers were also asked for their perception of the impact of the ETS on the core business operations of their firm (see Table 4). One-third suggested it would have no impact, 3\% thought the impact on core business would be positive, $20 \%$ said it would have a negative impact and $43 \%$ were unsure of the impact (which parallels the general lack of understanding of the scheme previously mentioned). With regard to the expected impact of the ETS on core business operations, firm size was influential. Micro firms were more likely to expect the ETS to have a positive impact on their core business, whilst small firms were more likely to expect the impact to be negative $\left(\mathrm{X}^{2}(6)=38.011, \mathrm{p}<0.01\right.$, Cramer's $\left.\mathrm{V}=0.113\right)$. SMEs in the service sector were more likely to expect the ETS to have no impact on their core business, whilst manufacturing SMEs were more likely to report that they were unsure of the likely impact of the scheme on their core business $\left(X^{2}(3)=9.513, p<0.05\right.$, Cramer's $\left.V=0.079\right)$. Family-owned firms were more likely to think that the ETS would have a negative impact on core business, while non-family-owned firms were more likely to think that the scheme would have no impact on their core business $\left(X^{2}(3)=9.390, p<0.05\right.$, Cramer's $\mathrm{V}=0.080$ ). Male owner-managers were more likely to think that the scheme would have a negative impact on their core business, while female owner-managers were more likely to think that the scheme would have no

\begin{tabular}{lrr}
\hline Impact of the Emissions Trading Scheme on the core business of the firm & Firms & $\%$ \\
\hline Positive & 45 & $2.9 \%$ \\
Negative & 309 & $19.9 \%$ \\
No impact & 507 & $32.6 \%$ \\
Unsure what impact & 672 & $43.2 \%$ \\
No response & 21 & $1.4 \%$ \\
\hline
\end{tabular}

Table 4. SME owner-managers' perceptions of the impact of the New Zealand ETS on the firm's core business 
impact on their core business $\left(X^{2}(3)=26.646, p<0.01\right.$, Cramer's $\left.V=0.133\right)$. Given that less than one-quarter of the sample claimed to understand how the ETS worked, these findings must be viewed with some degree of scepticism, but point to the greatest willingness to engage with the scheme's intent residing in the smallest firms.

The ETS puts a price on carbon in order to reduce carbon related emissions, which large emitters say will make them uncompetitive and could cost jobs. Also shown in Table 3 are the responses of owner-managers to the question of whether large emitters should pay this price on carbon. Responses were reasonably evenly spread, with $37 \%$ disagreeing, $32 \%$ in agreement and $29 \%$ undecided or responding that they did not know. Micro enterprises were more likely than small or medium-sized enterprises to agree that large emitters should pay the new price on carbon $\left(\mathrm{F}(2,1480)=5.386, \mathrm{p}<0.01, \dot{\omega}^{2}=0.08\right)$. In addition, manufacturing SMEs were more likely (than service SMEs) to disagree that large emitters should pay the price on carbon $(t(1517)=2.368, p<0.05, r=0.06)$.

The ISO 14000 series of environmental management standards provide guidelines, principles and general supporting practices designed to help an organization develop and implement an EMS. Specifically, the standards address environmental assessments, environmental auditing, environmental performance evaluation, environmental labelling and declarations, lifecycle assessments, and integration of environmental issues into product design. While firms can independently implement their own EMS, at the heart of the ISO 14000 series, ISO 14001 prescribes requirements for implementing and maintaining an EMS, providing the opportunity for organizations to become certified through registered third-party auditors (Babakri et al., 2004; Potoski and Prakash, 2005; Zutshi and Sohal, 2004).

Most SME owner-managers surveyed, 1308 (84\%), were not aware of the ISO14001 EMS standard. Of the 229 (15\%) who knew of the standard, six firms were certified and a further six were currently working toward certification. An additional 44 owner-managers were open to certification (at least in the long term), but 128 said they would not consider certification (and 31were unsure). Firm size was relevant when it came to knowledge of the ISO 14001 EMS standard. Significantly more micro firms were unaware of the standard than were small and medium-sized enterprises $\left(X^{2}(2)=9.797, p<0.01\right.$, Cramer's $\left.V=0.081\right)$. However, medium-sized enterprises were no more likely to have or to consider ISO 14001 certification than micro or small enterprises.

Table 5 presents the responses by $143 \mathrm{SME}$ owner-managers regarding perceived barriers contributing to their decision not to consider ISO 14001 certification. Documentation and preparation was identified as the foremost barrier to ISO 14001 certification, with $83 \%$ of owner-managers identifying it as such. External resource costs and internal audit costs were identified as barriers to certification by $76 \%$ and $69 \%$ of owner-managers respectively. These findings are consistent with those of other studies, which have identified the same barriers as significant in relation to ISO 14001 implementation in the SME context (e.g. Biondi et al., 2000; Cassells et al., 2011; Hillary, 2004; Watson and Emery, 2004). Small firms were likely to consider the lack of specialists in the field as a barrier to ISO 14001 certification, whilst micro firms $\operatorname{did} \operatorname{not}\left(X^{2}(2)=9.919, p<0.01\right.$, Cramer's V=0.269). The same was the case for family-owned SMEs as compared with non-family-owned SMEs $\left(X^{2}(1)=5.606, p<0.05\right.$, Cramer's $\mathrm{V}=0.200$ ). Younger owner-managers were more likely to consider internal audit costs as a barrier to certification

\begin{tabular}{|c|c|c|c|c|}
\hline \multirow{2}{*}{ Barriers to ISO 14001 certification } & \multicolumn{2}{|c|}{ Yes } & \multicolumn{2}{|c|}{ No } \\
\hline & Firms & $\%$ & Firms & $\%$ \\
\hline Documentation preparation and maintenance & 118 & 82.5 & 25 & 17.5 \\
\hline Internal audit costs & 98 & 68.5 & 45 & 31.5 \\
\hline External resource costs & 108 & 75.5 & 35 & 24.5 \\
\hline Scope of legislative requirements & 66 & 46.2 & 77 & 53.8 \\
\hline Management involvement & 64 & 44.8 & 79 & 55.2 \\
\hline Employee involvement and training & 55 & 38.5 & 88 & 61.5 \\
\hline Monitoring and measurement & 74 & 51.7 & 69 & 48.3 \\
\hline Lack of specialists in the field & 46 & 32.2 & 97 & 67.8 \\
\hline Training of contractors regarding EMS requirements & 40 & 28.0 & 103 & 72.0 \\
\hline Scope of the organization's environmental aspects and impact & 38 & 26.6 & 105 & 73.4 \\
\hline The need to disclose confidential information to a third party & 37 & 25.9 & 106 & 74.1 \\
\hline
\end{tabular}

Table 5. Perceived barriers to ISO 14001 certification 
than their older counterparts $\left(X^{2}(1)=4.479, p<0.05\right.$, Cramer's $\left.V=0.249\right)$. In addition, female owner-managers were more likely to consider the scope of legislative requirements a barrier to ISO 14001 certification than their male counterparts $\left(X^{2}(1)=4.509, p<0.05\right.$, Cramer's $\left.V=0.178\right)$.

\section{Collaboration}

Firm collaboration was the focus of a section of the earlier survey, which received responses from 1361 SME owner-managers. When asked whether they thought that collaboration with other firms could improve the competitive strength of their firm, 1011 owner-managers (74\%) said 'yes' and 244 (18\%) said 'no' (8\% did not respond). Firm size was significant, with owner-managers of small and medium-sized enterprises more likely to report that collaboration improved their competitive strength, relative to micro firms $\left(X^{2}(2)=22.170, p<0.01\right.$, Cramer's $V=0.134)$. In addition, younger owner-managers were more likely than their older counterparts to report that collaboration could improve the firm's competitive strength $\left(X^{2}(2)=22.420, p<0.01\right.$, Cramer's $\mathrm{V}=0.134)$.

When it came to actually collaborating, however, only 329 firms (24\%) of the 1361 firms surveyed had at least one formal collaboration based on a written agreement or contract ( $8 \%$ did not respond). These firms collaborated formally with an average of six other firms. Two-thirds of the 329 firms collaborated formally with up to three firms and $12 \%$ with at least ten firms. A greater number of firms had at least one informal collaboration based on a verbal agreement, previous experience or trust. Of the 1361 surveyed, 589 firms (43\%) had an informal collaboration with at least one other firm ( $5 \%$ did not respond). These firms collaborated informally with an average of ten other firms (55\% collaborated informally with up to three firms and $18 \%$ with at least ten firms). Firm size mattered when it came to both formal and informal collaboration. Relative to small and medium firms, micro firms were less likely to collaborate either formally $\left(X^{2}(2)=20.220, p<0.01\right.$, Cramer's $\left.V=0.126\right)$ or informally $\left(X^{2}(2)=19.721, p<0.01\right.$, Cramer's $V=0.125)$. SMEs in the service sector had a greater number of formal collaborations than manufacturing firms $(\mathrm{t}(285)=-1.929, \mathrm{p}<0.05, \mathrm{r}=0.11)$ and were also more likely than manufacturers to collaborate informally $\left(X^{2}(1)=6.118, p<0.05\right.$, Cramer's $\left.V=0.069\right)$. Male owner-managers were more likely to report that they had informal collaboration with other firms than their female counterparts $\left(X^{2}(1)=20.320, p<0.01\right.$, Cramer's $\mathrm{V}=0.126$ ). However, firms with female owner-managers that did collaborate informally had a greater number of informal collaborations than firms with male owner-managers $(\mathrm{t}(472)=-2.245, \mathrm{p}<0.05, \mathrm{r}=0.103)$.

The perceived benefits of collaborating with other firms are presented in Table 6. SME owner-managers responded to suggested benefits, from 'strongly agree' (assigned 1) through to 'strongly disagree' (assigned 5), and from the individual responses the mean response (and standard deviation) were calculated. The lower the mean, the greater the agreement with the suggested benefit. From these mean scores the benefits can be ranked in order. 'Access to new and larger markets' was the foremost perceived benefit of collaboration, with $84 \%$ of the 1137 respondents to this statement either agreeing or strongly agreeing that it was a benefit of collaboration. 'Access to know-how and technology' and 'broader supply of products/services' were next, with $79 \%$ of respondents for each either agreeing or strongly agreeing that they were benefits of collaboration. 'Additional production capacity' was the fourth perceived benefit of collaboration.

\begin{tabular}{|c|c|c|c|c|c|c|c|c|}
\hline $\begin{array}{l}\text { Perceived benefits } \\
\text { of collaboration }\end{array}$ & $\begin{array}{c}\text { Strongly } \\
\text { agree }\end{array}$ & Agree & $\begin{array}{r}\text { Neither agree } \\
\text { nor disagree }\end{array}$ & Disagree & $\begin{array}{l}\text { Strongly } \\
\text { disagree }\end{array}$ & $\begin{array}{l}\text { No. of firms } \\
\text { responding }\end{array}$ & Mean & St. dev. \\
\hline Access to new and larger markets & $28.8 \%$ & $55.1 \%$ & $12.0 \%$ & $3.0 \%$ & $1.1 \%$ & 1137 & 1.92 & 0.786 \\
\hline Access to know-how and technology & $22.8 \%$ & $56.1 \%$ & $16.6 \%$ & $3.5 \%$ & $1.1 \%$ & 1123 & 2.04 & 0.792 \\
\hline Broader supply of products/services & $22.9 \%$ & $55.6 \%$ & $16.3 \%$ & $4.0 \%$ & $1.2 \%$ & 1088 & 2.05 & 0.812 \\
\hline Additional production capacity & $13.6 \%$ & $50.2 \%$ & $26.1 \%$ & $7.9 \%$ & $2.2 \%$ & 1022 & 2.35 & 0.887 \\
\hline Reduced costs & $13.7 \%$ & $43.7 \%$ & $30.1 \%$ & $10.5 \%$ & $2.0 \%$ & 1039 & 2.44 & 0.923 \\
\hline Access to labour & $11.5 \%$ & $43.7 \%$ & $29.7 \%$ & $11.9 \%$ & $3.2 \%$ & 1054 & 2.52 & 0.954 \\
\hline Access to capital & $5.9 \%$ & $24.6 \%$ & $43.7 \%$ & $20.4 \%$ & $5.3 \%$ & 974 & 2.95 & 0.947 \\
\hline
\end{tabular}

Table 6. Perceived benefits of collaboration 
Perceived benefits of collaboration were independent of firm size. Service firms, however, were more likely than manufacturers to agree that collaboration opens up access to know-how and technology $(\mathrm{t}(1121)=3.170, \mathrm{p}$ $0.01, \mathrm{r}=0.09)$, brings the benefit of a broader supply of products/services $(\mathrm{t}(1086)=3.413, \mathrm{p}<0.01, \mathrm{r}=0.10)$ and can lead to reduced costs $(\mathrm{t}(1037)=1.981, \mathrm{p}<0.05, \mathrm{r}=0.06)$. Family-owned firms were also more likely (than non-family firms) to agree that collaboration can lead to reduced costs $(t(1017)=2.360, p<0.05, r=0.07)$. Manufacturing firms were more likely than service firms to agree that collaboration results in additional production capacity $(\mathrm{t}(1020)=-4.060, \mathrm{p}<0.01, \mathrm{r}=0.13)$, and that it opens up access to labour $(\mathrm{t}(1052)=-2.363, \mathrm{p}$ $<0.05, \mathrm{r}=0.07)$. Younger owner-managers were more likely than their older counterparts to 'strongly agree' that collaboration can provide access to new and larger markets $(\mathrm{t}(1125)=-2.125, \mathrm{p}<0.05, \mathrm{r}=0.06)$, and were also more likely to 'agree' that it can provide access to labour $(\mathrm{t}(1044)=-2.400, \mathrm{p}<0.05, \mathrm{r}=0.074)$. In addition, females were also more likely than males to agree that collaboration opened up access to labour $(\mathrm{t}(1044)=3.016, \mathrm{p}<0.01, \mathrm{r}$ $=0.09)$ and to a broader supply of products/services $(\mathrm{t}(1077)=2.929, \mathrm{p}<0.01, \mathrm{r}=0.09)$.

The perceived barriers to collaboration are presented in Table 7. Again, owner-managers responded to suggested barriers, from 'strongly agree' through to 'strongly disagree', from which the mean (and standard deviation) was calculated. The lower the mean, the greater the agreement with the suggested barrier. The 'wish to maintain independence' was the primary perceived barrier to collaboration, with $75 \%$ of the 1181 respondents to this statement either agreeing or strongly agreeing that it was a barrier to collaboration. 'Not wishing to disclose sensitive information' was a close second, with $62 \%$ of respondents either agreeing or strongly agreeing that this was a barrier to collaboration, and the third ranked barrier was the 'high risk involved'. The primary barrier to collaboration, the 'wish to maintain independence', was the only barrier that showed a significant difference with respect to firm size. Micro firms were more likely to consider this a barrier than small and medium sized firms $(\mathrm{F}(2,1154)=5.883, \mathrm{p}<0.01$, $\left.\dot{\omega}^{2}=0.09\right)$. In addition, service firms were more likely to consider this a barrier than manufacturing firms $(\mathrm{t}(1179)=2.531$, $\mathrm{p}<0.05, \mathrm{r}=0.07)$, as were male owner-managers $(\mathrm{t}(1170)=2.168, \mathrm{p}<0.05, \mathrm{r}=0.06)$. Female owner-managers were more likely than their male counterparts to agree that 'lack of information on suitable firms with which to collaborate' is a barrier to collaboration $(\mathrm{t}(996)=3.640, \mathrm{p}<0.01, \mathrm{r}=0.11)$, as well as there being a 'high risk involved' in collaborating with other firms $(\mathrm{t}(967)=2.170, \mathrm{p}<0.05, \mathrm{r}=0.06)$.

Finally, we examined whether there was any significant difference in the response to environmental issues by the owner-managers of those firms with formal collaborations and those without, and again of those with informal collaborations and those without. These data were drawn from the 740 SME owner-managers who responded to both the questions from both waves of the survey. When comparing those firms engaged in formal collaboration with those that do not collaborate, it was found that there were no significant differences in attitudes regarding responsibility for the environment, the ETS, knowledge of ISO 14001 or barriers to certification, with the exception of one relatively minor barrier to ISO 14001 uptake. Similarly, with regard to firms that engage in informal collaboration as compared with those that do not collaborate, there were no significant differences regarding attitudes to environmental issues, knowledge of ISO 14001 or barriers to certification.

\begin{tabular}{|c|c|c|c|c|c|c|c|c|}
\hline $\begin{array}{l}\text { Perceived barriers for collaborating } \\
\text { with other firms }\end{array}$ & Strongly agree & Agree & $\begin{array}{r}\text { Neither agree } \\
\text { nor disagree }\end{array}$ & Disagree & $\begin{array}{l}\text { Strongly } \\
\text { disagree }\end{array}$ & $\begin{array}{l}\text { No. of firms } \\
\text { responding }\end{array}$ & Mean & St. dev \\
\hline Wish to maintain independence & $20.9 \%$ & $53.7 \%$ & $16.8 \%$ & $7.7 \%$ & $0.9 \%$ & 1181 & 2.14 & 0.866 \\
\hline $\begin{array}{l}\text { Do not wish to disclose sensitive } \\
\text { information }\end{array}$ & $17.2 \%$ & $44.8 \%$ & $26.1 \%$ & $10.5 \%$ & $1.5 \%$ & 1086 & 2.34 & 0.932 \\
\hline High risk involved & $10.8 \%$ & $36.1 \%$ & $35.6 \%$ & $15.7 \%$ & $1.8 \%$ & 1045 & 2.62 & 0.936 \\
\hline $\begin{array}{l}\text { Lack of information on suitable } \\
\text { firms with which to collaborate }\end{array}$ & $7.6 \%$ & $29.4 \%$ & $39.7 \%$ & $18.9 \%$ & $4.5 \%$ & 1005 & 2.83 & 0.968 \\
\hline Restrictions imposed by taxation & $5.2 \%$ & $21.0 \%$ & $53.4 \%$ & $17.0 \%$ & $3.4 \%$ & 1001 & 2.92 & 0.847 \\
\hline
\end{tabular}
or legal regulation 


\section{Conclusions}

Responses from this sample of SMEs displayed some degree of willingness to abdicate responsibility in relation to the environment. They were prepared to share responsibility (with government) for the environment, but did not consider that the lead in this regard should be coming collectively from the sector as a whole. Such a perception may continue to be a significant impediment to SME participation in voluntary environmental initiatives, or those that rely upon a position of pro-activity as opposed to a response mandated by compliance oriented requirements. In a similar vein, responses from this sample of SMEs indicated discontent in relation to New Zealand assuming a position of leadership on the global stage in relation to climate change. Instead, the majority of respondents would be reportedly more satisfied if the country kept pace with other nations, or did very little. This is underpinned by their disagreement with New Zealand's ETS as a policy approach. However, the robustness of this disagreement, along with the veracity of the assessment of respondents as to the impact of the ETS on their firms, may be questionable given the lack of comprehension of the scheme reflected in questionnaire responses.

If SMEs in the study collaborated, it tended to be informally, and the gender and age of owner-manager influenced the decision to initiate collaborative activities (women and those younger in age were more amenable). Access to knowledge was the collaborative benefit most frequently identified by participants; however, the perceived competitive advantages of collaboration were insufficient to subsequently stimulate any action. Firms that collaborated showed no differences in their responses to environmental issues than their non-collaborating counterparts. This finding is unsurprising on the whole, given the lack of pervasiveness of collaborative approaches to environmental issues in New Zealand in general. An interpretation of the findings is that there may, going forward, be merit in specifically evaluating the potential for collaborative approaches by SMEs to environmental management issues. This suggestion is legitimized in part by the positive attitude to collaboration evidenced by the sample group of SMEs reported in this paper. Further, the collaborating firms' responses did not show that they had any less regard for the environment than the non-collaborating participants.

If a collaborative orientation to environmental issues were to be explored as a possibility for SMEs in New Zealand, findings from this study show that these collaborative relationships might need to be established for, or facilitated by, intermediaries, or initially stimulated by a compliance related framework (as opposed to being independently initiated and sustained by the firms themselves). This conclusion is primarily based upon the fact that the results of the study reflected that, even if SME owner-managers were able to identify advantages to operating in a collaborative fashion, these perceptions were insufficient to spur them to change their existing patterns of operation, or to initiate collaborative alliances. However, this is not to say that if an external organization were to facilitate access to some type of collaborative alliance SMEs would not participate.

It would seem that there may exist the potential for existing organizations (either with a trade or industry focus) or networks (with an environmental focus) to begin thinking about ways to engage SMEs collectively and cooperatively, rather than individually and independently as traditionally has been the case. The primary role for such organizations at this stage of the evolution of green thinking for SMEs in New Zealand may be in the provision of information and expertise (rather than initiatives and programmes). However, given the clear environmental information gap that demonstrably exists in the SME context, this would be no small contribution. It may also be an 'easy win' to establish the merits of a co-operative (rather than adversarial) orientation, given that our findings showed that SME owner-managers are already well aware of the knowledge generating capabilities of external relationships.

Instead of consigning the plight of SMEs and their general lack of environmental engagement to the 'too hard' basket, it may be time to give serious consideration to the merits of alternative approaches to encouraging them to think and behave sustainably. In parallel, specific attention could to be given to investigating those who are already leading and/or working collaboratively in this regard in order to attempt to transfer learning from those contexts into others where levels of environmental consciousness are poor and corresponding activity in relation to sustainability weak. Environmental indicators continue to warn of the speed with which business needs to act as a collective to enact mass change in terms of environmental practices. Collaborative relationships may have the power to both educate and engage in the SME context, and ultimately trigger a level of environmental empowerment that may tip SMEs from being laggards to commencing the path to environmental leadership - or, for those already 
leading, to take a leadership role in a collective rather than individual sense.

Table 7. Perceived barriers to collaboration 


\section{References}

Agan Y, Acar MF, Borodin A. 2013. Drivers of environmental processes and their impact on performance: a study of Turkish SMEs. Journal of Cleaner Production 51: 23-33.

Aragon-Correa JA, Hurtado-Torres N, Sharma S, Garcia-Morales VJ. 2008. Environmental strategy and performance in small firms: a resourcebased perspective. Journal of Environmental Management 86: 88-103.

Armstrong JS, Overton TS. 1977. Estimating nonresponse bias in mail surveys. Journal of Marketing Research 16: $396-402$.

Ayuso S, Roca M, Colome R. 2013. SMEs as 'transmitters' of CSR requirements in the supply chain. Supply Chain Management 18(5): 497-508.

Babakri KA, Bennett RA, Rao S, Franchetti M. 2004. Recycling performance of firms before and after adoption of the ISO 14001 standard. Journal of Cleaner Production 12: 633-637.

Bartholomew S, Smith A. 2006. Improving survey response rates from chief executive officers in small firms: the importance of social networks. Entrepreneurship: Theory and Practice 30(1): 83-96.

Battisti M, Perry M. 2011. Walking the talk? Environmental responsibility from the perspective of small-business owners. Corporate Social Responsibility and Environmental Management 18: 172-185.

Bertram G, Terry S. 2010. The Carbon Challenge. New Zealand's Emissions Trading Scheme. Bridget Williams Books: Wellington.

Bianchi R, Noci G. 1998. 'Greening' SMEs' competitiveness. Small Business Economics 11: 269-281.

Biondi V, Frey M, Iraldo F. 2000. Environmental management systems and SMEs: motivations, opportunities and barriers related to EMAS and ISO 14001 implementation. Greener Management International Spring 29: 55-69.

Burch S, Schroeder H, Rayner S, Wilson J. 2013. Novel multisector networks and entrepreneurship: the role of small businesses in the multilevel governance of climate change. Environment and Planning C: Government and Policy 31: 822-840.

Brammer S, Hoejmose S, Marchant K. 2012. Environmental management in SMEs in the UK: practices, pressures and perceived benefits. Business Strategy and the Environment 21: 423-434.

Cameron A, Massey C. 1999. Small and Medium Sized Enterprises: a New Zealand Perspective. Addison Longman Wesley: Auckland.

Cassells S, Lewis K. 2011. SMEs and environmental responsibility: do actions reflect attitudes? Corporate Social Responsibility and Environmental Management 18(3): 186-199.

Cassells S, Lewis K, Findlater A. 2011. SMEs and ISO 14001 adoption: a New Zealand perspective. Small Enterprise Research 18(1): 19-32.

Chaston I, Mangles T. 2000. Business networks: assisting knowledge management and competence acquisition within UK manufacturing firms. Journal of Small Business and Enterprise Development 7(2): 160-170.

Cheung DKK, Welford RJ, Hills PR. 2009. CSR and the environment: business supply chain partnerships in Hong Kong \& PRDR, China. Business Strategy and the Environment 16: 250-263.

Ciliberti F, Pontrandolfo P, Scozzi B. 2008. Investigating corporate social responsibility in supply chains: a SME perspective. Journal of Cleaner Production 16: 1579-1588

Collins E, Lawrence S, Pavlovich K, Ryan C. 2007. Business networks and the uptake of sustainability practices: the case of New Zealand. Journal of Cleaner Production 15: 729-740.

Collins E, Roper J, Lawrence S. 2010. Sustainability practices: trends in New Zealand businesses. Business Strategy and the Environment 19: 479-494.

Cote R, Booth A, Louis B. 2006. Eco-efficiency and SMEs in Nova Scotia, Canada. Journal of Cleaner Production 14: 542-550.

Coviello N, Munro H. 1997. Network relationships and the internationalisation process of small software firms. International Business Review 6(4): 361-386.

del Brio JA, Junquera B. 2003. A review of the literature on environmental innovation management in SMEs: implications for public policies. Technovation 23: 939-948.

Dewhurst H, Thomas R. 2003. Encouraging sustainable business practices in a non-regulatory environment: a case study of small tourism firms in a UK national park. Journal of Sustainable Tourism 11(5): 383-403.

Dillman D. 2000. Mail and Internet Surveys: the Tailored Design Method (2nd edn). Wiley: New York.

Drake F, Purvis M, Hunt J. 2004. Meeting the environmental challenge: a case of win-win or lose-win? A study of the UK baking and refrigeration industries. Business Strategy and the Environment 13: 172-186.

European Commission. 2002. Observatory of European SMEs 2002/No 4: European SMEs and Social and Environmental Responsibility. European Communities: Luxembourg.

Gadenne DL, Kennedy J, McKeiver C. 2009. An empirical study of environmental awareness and practices in SMEs. Journal of Business Ethics 84: $45-63$.

Gombault M, Versteege S. 1999. Cleaner production in SMEs through a partnership with (local) authorities: successes from the Netherlands. Journal of Cleaner Production 7: 249-261.

Gonzalez-Benito J, Gonzalez-Benito O. 2005. Environmental proactivity and business performance: an empirical analysis. Omega 33: 1-15.

Halme M, Fadeeva Z. 2000. Small and medium-sized tourism enterprises in sustainable development networks. Greener Management International 30: $97-113$.

Halme M, Korpela M. 2013. Responsible innovation towards sustainable development in small and medium-sized enterprises: a resource perspective. Business Strategy and the Environment. DOI: 10.1002/bse.1801.

Hansen EG, Klewitz J. 2013. The role of an SME's green strategy in public-private eco-innovation initiatives: the case of Ecoprofit. Journal of Small Business and Entrepreneurship 25(4): 451-478.

Hillary R. 2004. Environmental management systems and the smaller enterprise. Journal of Cleaner Production 12: 561-569. 
Hoevenagel R, Wolters T. 2000. Small and medium-sized enterprises, environmental policies and the supporting role of intermediate organisations in the Netherlands. Greener Management International 30: 61-69.

Hofmann KH, Theyel G, Wood CH. 2012. Identifying firm capabilities as drivers of environmental management and sustainability practices evidence from small and medium sized manufacturers. Business Strategy and the Environment 21:530-545.

Holland L, Gibbon J. 1997. SMEs in the metal manufacturing, construction and contracting service sectors: environmental awareness and actions. Eco-Management and Auditing 4: 7-14.

Howarth R, Fredericks J. 2012. Sustainable SME practice: a reflection on supply-chain environmental management intervention. Management of Environmental Quality 23(6): 673-685.

Huppe F, Turgeon R, Ryan T, Vanasse C. 2006. Fostering pollution prevention in small businesses: the Enviroclub initiative. Journal of Cleaner Production 14: 563-571.

Hutchinson A, Hutchinson F. 1995. Sustainable regeneration of the UK's small and medium-sized enterprise sector: some implications of SME response to BS 7750. Greener Management International 9: 73-84.

Ilomaki M, Melanen M. 2001. Waste minimisation in small and medium-sized enterprises - do environmental management systems help? Journal of Cleaner Production 9: 209-217.

Kearins K, Collins E. 2012. Making sense of ecopreneurs' decision to sell up. Business Strategy and the Environment 21: 71-85.

Klewitz J, Zeyen A, Hansen EG. 2012. Intermediaries driving eco-innovation in SMEs: a qualitative investigation. European Journal of Innovation Management 15(4): 442-467.

Lawrence SR, Collins E, Pavlovich K, Arunachalam M. 2006. Sustainability practices of SMEs: the case of NZ. Business Strategy and the Environment 15: 242-257.

Lepoutre J, Heene A. 2006. Investigating the impact of firm size on small business social responsibility: a critical review. Journal of Business Ethics 67: $257-273$.

Malone K. 2001. Children, youth and sustainable cities. Local Environment 6(1): 5-12.

Masurel E. 2007. Why SMEs invest in environmental measures: sustainability evidence from small and medium-sized printing firms. Business Strategy and the Environment 16: 190-201.

Ministry of Economic Development (MED). 2011. SMEs in New Zealand: Structure and Dynamics 2011. MED: Wellington, New Zealand.

Mir DF. 2008. Environmental behaviour in Chicago automotive repair micro-enterprises (MEPs). Business Strategy and the Environment 17: 194-207.

Mir DF, Feitelson E. 2007. Factors affecting environmental behavior in micro-enterprises: laundry and motor vehicle repair firms in Jerusalem. International Small Business Journal 25(4): 383-415.

Moore SB, Manring SL. 2009. Strategy development in small and medium sized enterprises for sustainability and increased value creation. Journal of Cleaner Production 17: 276-282.

Parker CM, Redmond J, Simpson M. 2009. A review of interventions to encourage SMEs to make environmental improvements. Environment and Planning C: Government and Policy 27: 279-301.

Patton D, Baron PJ. 1995. Factors influencing companies' response to environmental responsibility. Eco-Management and Auditing 2: 41-46.

Patton D, Worthington I. 2003. SMEs and environmental regulations: a study of the UK screen-printing sector. Environment and Planning C: Government and Policy 21: 549-566.

Petts J. 2000. The regulator-regulated relationship and environmental protection: perceptions in small and medium-sized enterprises. Environment and Planning C: Government and Policy 18: 191-206.

Podsakoff PM, MacKenzie SB, Lee JY, Podsakoff NP. 2003. Common method biases in behavioural research: a critical review of the literature and recommended remedies. Journal of Applied Psychology 88(5): 879-903.

Potoski M, Prakash A. 2005. Green clubs and voluntary governance: ISO 14001 and firms' regulatory compliance. American Journal of Political Science 49(2): 235-248.

Pratt RM, Phillips PS. 2000. The role and success of UK waste minimisation clubs in the correction of market and information failures. Resources, Conservation and Recycling 30: 201-219.

Redmond J, Walker E, Wang C. 2008. Issues for small businesses with waste management. Journal of Environmental Management 88: $275-285$.

Revell A, Blackburn R. 2007. The business case for sustainability? An examination of small firms in the UK's construction and restaurant sectors. Business Strategy and the Environment 16: 404-420.

Revell A, Rutherfoord R. 2003. UK environmental policy and the small firm: boadening the focus. Business Strategy and the Environment 12 : $26-35$.

Revell A, Stokes D, Chen, H. 2009. Small businesses and the environment: turning over a new leaf? Business Strategy and the Environment 19(5): 273-288.

Rowe J, Hollingsworth D. 1996. Improving the environmental performance of small- and medium-sized enterprises: a study in Avon. Eco-Management and Auditing 3: 97-107.

Russo A, Perrini F. 2009. Investigating stakeholder theory and social capital: CSR in large firms and SMEs. Journal of Business Ethics 91(2): $207-221$.

Rutherfoord R, Blackburn RA, Spence LJ. 2000. Environmental management and the small firm: an international comparison. International Journal of Entrepreneurial Behaviour and Research 6(6): 310-325.

Setzer J, Biderman R. 2013. Increasing participation in climate policy implementation: a case for engaging SMEs from the transport sector in the city of Sao Paulo. Environment and Planning C: Government and Policy 31: 806-821.

Sharfman MP, Shaft TM, Enex RP Jr. 2009. The road to cooperative supply-chain environmental management: trust and uncertainty among proactive firms. Business Strategy and the Environment 18: 1-13.

Simpson M, Taylor N, Barker K. 2004. Environmental responsibility in SMEs: does it deliver competitive advantage? Business Strategy and the Environment 13: 156-171. 
Stern N. 2007. The Economics of Climate Change. The Stern Review. Cambridge University Press: Cambridge.

Studer S, Welford R, Hills P. 2006. Engaging Hong Kong businesses in environmental change: drivers and barriers. Business Strategy and the Environment 15: 416-431.

Taylor N, Barker K, Simpson M. 2003. Achieving 'sustainable business': a study of perceptions of environmental best practices by SMEs in South Yorkshire. Environment and Planning C: Government and Policy 21: 89-105.

Tilley F. 1999. The gap between the environmental attitudes and the environmental behaviour of small firms. Business Strategy and the Environment 8: 238-248.

Tilley F, Hooper P, Walley L. 2003. Sustainability and competitiveness: are there mutual advantages for SMEs? In Competitive Advantage in SMEs: Organising for Innovation and Change, Jones O, Tilley F (eds). Wiley: Chichester; 71-84.

Tzschentke NA, Kirk D, Lynch PA. 2008. Going green: decisional factors in small hospitality operations. International Journal of Hospitality Management 27: 126-133.

Verheul H. 1999. How social networks influence the dissemination of cleaner technologies to SMEs. Journal of Cleaner Production 7: 213-219.

Vernon J, Essex S, Pinder D, Curry K. 2003. The 'greening' of tourism micro-businesses: outcomes of focus group investigations in South East Cornwall. Business Strategy and the Environment 12: 49-69.

Watson M, Emery ART. 2004. Environmental management and auditing systems: the reality of environmental self-regulation. Managerial Auditing Journal 19(7): 916-928.

Welford R. 1994. Barriers to the improvement of environmental performance: the case of the SME sector. In Cases in Environmental Management and Business Strategy, Welford R (ed.). Pitman: London; 152-165.

Williams S, Schaefer A. 2013. Small and medium-sized enterprises and sustainability: managers' values and engagement with environmental and climate change issues. Business Strategy and the Environment 22: 173-186.

Williamson D, Lynch-Wood G. 2001. A new paradigm for SME environmental practice. TQM Magazine 13(6): 424-432.

Williamson D, Lynch-Wood G, Ramsay J. 2006. Drivers of environmental behaviour in manufacturing SMEs and the implications for CSR. Journal of Business Ethics 67: 317-330.

Wilson CDH, Williams ID, Kemp S. 2011. Compliance with producer responsibility legislation: experiences from UK small and medium-sized enterprises. Business Strategy and the Environment 20: 310-330.

Wilson CDH, Williams ID, Kemp S. 2012. An evaluation of the impact and effectiveness of environmental legislation in small and medium-sized enterprises: experiences from the UK. Business Strategy and the Environment 21: 141-156.

Worthington I, Patton D. 2005. Strategic intent in the management of the green environment within SMEs. Long Range Planning 38: 197-212.

Wynarczyk P, Watson R. 2005. Firm growth and supply chain partnerships: an empirical analysis of U.K. SME subcontractors. Small Business Economics 24: 39-51.

Yarahmadi M, Higgins PG. 2012. Motivation towards environmental innovation: a conceptual framework for multi-party cooperation. European Journal of Innovation Management 15(4): 400-420.

Zutshi A, Sohal A. 2004. Environmental management system adoption by Australasian organisations: part 1: reasons, benefits and impediments. Technovation 24(4): 335-357. 